\title{
CSFs for the Implementation of the Hybrid Lean ERP System. Stakeholders Interactions
}

\author{
Mariam Houti*, Laila El Abbadi, Abdellah Abouabdellah \\ Systems Engineering Laboratory, National School of Applied Sciences of Kenitra, Ibn Tofail University, PoBox 241, Morocco
}

\begin{tabular}{l} 
A R T I C L E I N F O \\
\hline Article history: \\
Received: 21 October, 2019 \\
Accepted: 12 December, 2019 \\
Online: 25 December, 2019 \\
\hline
\end{tabular}

Keywords:

Lean ERP

CSFS

Performance

Stakeholders

\begin{abstract}
A B S T R A C T
Lean ERP system is considered among the new trends of systems in the manufacturing sector, it has become one of the most widely adopted systems, thanks to its various benefits such as: a centralized database which gathers all the data of the enterprise in a single database which is accessible to all the departments, reduction in costs, high performance and best quality and many other advantages. However, many companies are starting the implementation of the hybrid Lean ERP system without prior study of the project. This may lead to its improper implementation which can impact negatively the enterprise and its stakeholders.

It is in this context that our study aims to help future companies wishing to implement the hybrid Lean ERP system, through identification, study and an analysis of critical success factors (CSFs) of Lean ERP necessary to this implementation, while focusing on different groups of stakeholders and their interactions with CSFs.
\end{abstract}

\section{Introduction}

As businesses in manufacturing and service sectors are increasingly subject to global competition, the highly variable demand from customers and the growing variety of products on the market [1], enterprises face several challenges in order to maintain their places in the market, which requires the improvement of their performance and competitiveness $[2,3]$. Otherwise, it encourages them to increase productivity and product quality, reduce costs and cycle times, be more flexible and respect delivery deadlines [4].

In order to cope with these fluid conditions, manufacturers often use two strategies to face these challenges: implementing Lean practices and integrating information and communication systems, in particular ERP systems "Enterprise Resource Planning" [3]. This combined implementation gave birth to the new hybrid Lean ERP system, that combines the entire database of all department in a centralized one.

A good implementation of the hybrid Lean ERP system offers several benefits to the enterprise and its stakeholders through a significant reduction in costs, operating time and a considerable increase in performance and quality (which could be traced from raw material to finished good) which leads to: responding quickly to customer's needs. However, if the implementation is not well achieved, it could lead to serious problems and losses. It is

"Corresponding Author: Mariam Houti | Email: Mariam.houti@gmail.com therefore important to take into account the different parts of the company and critical success factors (CSFs) to ensure the successful implementation of the hybrid system.

The purpose of this Research is to identify Critical Success Factors (CSFs) for the implementation of the hybrid Lean ERP system, then study the degree of influence of the CSFs in order to extract the most decisive factors during implementation. Afterward, explore the role of stakeholders in the implementation of the hybrid system, in order to categorize which factors directly influence them, for the purpose of a successful implementation within the enterprise and its stakeholders.

\section{CSFs For Lean ERP System}

Critical success factors are all elements to consider when setting up or upgrading a new system, to optimize resources and effort by focusing on the important elements that contribute to successful implementation or upgrade. As a result, many researchers had shed more light on those factors (CSFs) and defined them according to their own points of view; the reason why we find different definition to CSFs in the literature.

Critical success factors usually vary from one industry to another, they define the elements influenced by the decisions of the top management and could affect the global competitive position of diverse sectors of an industry [5]. CSFs tend to relate more to how an organization approaches the change effort versus 


\section{Houti et al. / Advances in Science, Technology and Engineering Systems Journal Vol. 4, No. 6, 443-447 (2019)}

change method specific factors. Even though certain authors bring up key aspects for the specific change method, most CSF are fairly general in nature [6]. Houti concluded that the concept of critical success factors is one of the important elements that influence the success of any organization. It should be used when implementing a system. As they are among the few elements that guarantee successful implementation in all phases: pre-implementation, implementation and post-implementation. While ensuring the sustainability of the system, through the use of factors of measurement of profitability and performance, as well as the respect of the different characteristics and conditions imposed in the specifications of the business [4]. Knowing that CSFs can have a direct positive or negative effect on the performance of the business. In fact, if they are well identifiable and applied, they can lead to the achievement of the business. On the other hand, if they are not used accurately they can lead to failure [4].

Several authors have discussed the critical factors whether success or Failure. Researchers have already identified according to the literature that CSFs affecting the implementation of both production systems, namely: Lean Manufacturing and ERP system. Our study is based on the work established by Houti and al., [4, 2] to gather the most critical success factors of Lean ERP system. It will be necessary to identify factors of success to guarantee an effective implementation of the combined system.

Our study allowed us to identify 20 different critical factors of success during the Implementation of the combined Lean ERP system. They cover the categories of management, resources and organizations, as well as the phases of implementation the Lean ERP system. The factors gathered are listed in the table 1:

\section{Table 1. CSFs for Lean ERP implementation}

\begin{tabular}{l}
\hline CSFs \\
\hline C 1. Top management support and commitment \\
C 2. Project management and planning \\
C 3. Change management / Organizational culture / Political issues; \\
C 4. Business plan and a clear vision; \\
C 5. Training and education; \\
C 6. Effective Interdepartmental communication; \\
C 7. Dedicated resources; \\
C 8. Adequate ERP software selection and good Lean tools; \\
C 9. Project monitoring and evaluation of performance; \\
C 10. Active, strategic and visionary leadership; \\
C 11. Suitable IT legacy systems; \\
C 12. Interdepartmental cooperation; \\
C 13. Skills and expertise; \\
C 14. Involvement of stakeholders; \\
C 15. Management of expectations; \\
C 16. Implementation Strategies; \\
C 17. Business Process Reorganization (BPR); \\
C 18. Project selection and prioritization; \\
C 19. On-going support (Customer, vendor); \\
C 20. Motivation;
\end{tabular}

\subsection{Degree of Influence Of Csfs For Lean ERP Implementation}

These 20 CSFs identified above have several interactions with each other. Our study is established thanks to an effective collaboration with a team of researchers and industrialists, in order to extract the different relations existing between each of these factors, and which are visualized later using the vectograph drawing method, represented in FIG. 1, where:

- The "X" represents the factors on the columns influence the factors on the rows.

- The "O" represents the factors on the rows influence the factors on the columns;

\begin{tabular}{|c|c|c|c|c|c|c|c|c|c|c|c|c|c|c|c|c|c|c|c|c|}
\hline $\mathrm{x}$ & $\mathrm{x}$ & $\mathrm{x}$ & $\mathrm{x}$ & $\mathrm{x}$ & $\mathrm{x}$ & $\mathrm{x}$ & $\mathrm{x}$ & $\mathrm{x}$ & $\mathrm{x}$ & $\mathrm{x}$ & $\mathrm{x}$ & $\mathrm{x}$ & $\mathrm{x}$ & $\mathrm{x}$ & $\mathrm{x}$ & $\mathrm{x}$ & $\mathrm{x}$ & $\mathrm{x}$ & $\mathrm{x}$ & $\mathrm{C}_{21}$ \\
\hline \multirow[t]{2}{*}{$\mathrm{x}$} & & $\mathrm{x}$ & & & $\mathrm{x}$ & $\mathrm{x}$ & $\mathrm{x}$ & & $\mathrm{x}$ & & 0 & & & & 0 & & & $\mathrm{x}$ & $\mathrm{C}_{20}$ & \\
\hline & & & & 0 & & $\mathrm{x}$ & $\mathrm{x}$ & 0 & & & $\mathrm{x}$ & 0 & $\mathrm{x}$ & & 0 & 0 & & $\mathrm{C} 19$ & & \\
\hline \multirow[t]{2}{*}{$\mathrm{x}$} & $\mathrm{x}$ & $\circ$ & $\mathrm{x}$ & $\circ$ & $\circ$ & 0 & $\circ$ & & $\mathrm{x}$ & & & & & & 0 & 0 & C18 & & & \\
\hline & $\mathrm{x}$ & & $\mathrm{x}$ & 0 & & & $\mathrm{x}$ & $\circ$ & & 0 & $\mathrm{x}$ & $\mathrm{x}$ & $\mathrm{x}$ & 0 & $\mathrm{x}$ & $\mathrm{Cl} 7$ & & & & \\
\hline $\mathrm{x}$ & $\mathrm{x}$ & $\mathrm{x}$ & $\mathrm{x}$ & & $\mathrm{x}$ & & $\mathrm{x}$ & $\circ$ & & $\mathrm{x}$ & $\mathrm{x}$ & $\mathrm{x}$ & $\mathrm{x}$ & 0 & $\mathrm{Cl} 16$ & & & & & \\
\hline $\mathrm{x}$ & $\mathrm{x}$ & $\mathrm{x}$ & & $\mathrm{x}$ & $\mathrm{x}$ & & & $\mathrm{x}$ & & & & & $\mathrm{x}$ & C15 & & & & & & \\
\hline \multirow[t]{2}{*}{$\mathrm{x}$} & $\mathrm{x}$ & $\circ$ & $\mathrm{x}$ & 0 & $\mathrm{x}$ & $\mathrm{x}$ & & 0 & $\mathrm{x}$ & & 0 & & $\mathrm{Cl4}$ & & & & & & & \\
\hline & $\mathrm{x}$ & $\mathrm{x}$ & $\mathrm{x}$ & 0 & & 0 & & 0 & & 0 & & $\mathrm{Cl} 13$ & & & & & & & & \\
\hline \multirow[t]{2}{*}{$\mathrm{x}$} & $\mathrm{x}$ & 0 & & $\circ$ & $\mathrm{x}$ & & $\circ$ & & $\mathrm{x}$ & & $\mathrm{Cl} 12$ & & & & & & & & & \\
\hline & $\mathrm{x}$ & $\circ$ & 0 & 0 & & 0 & 0 & & & c11 & & & & & & & & & & \\
\hline 0 & $\circ$ & $\circ$ & 0 & & $\circ$ & & & $\circ$ & c10 & & & & & & & & & & & \\
\hline \multirow[t]{2}{*}{$\mathrm{x}$} & 0 & $\mathrm{x}$ & & $\mathrm{x}$ & $\circ$ & $\circ$ & $\mathrm{x}$ & $\mathrm{C} 9$ & & & & & & & & & & & & \\
\hline & $\mathrm{x}$ & 0 & $\mathrm{x}$ & 0 & & $\circ$ & $\mathrm{Cs}$ & & & & & & & & & & & & & \\
\hline $\mathrm{x}$ & $\mathrm{x}$ & $\circ$ & $\mathrm{x}$ & 0 & & C7 & & & & & & & & & & & & & & \\
\hline $\mathrm{x}$ & $\mathrm{x}$ & $\circ$ & $\mathrm{x}$ & & c6 & & & & & & & & & & & & & & & \\
\hline $\mathrm{x}$ & $\mathrm{x}$ & $\circ$ & $\mathrm{x}$ & C5 & & & & & & & & & & & & & & & & \\
\hline 0 & $\circ$ & $\circ$ & $\mathrm{C} 4$ & & & & & & & & & & & & & & & & & \\
\hline $\mathrm{x}$ & $\mathrm{x}$ & $\mathrm{C}_{3}$ & & & & & & & & & & & & & & & & & & \\
\hline $\mathrm{x}$ & $\mathrm{C} 2$ & & & & & & & & & & & & & & & & & & & \\
\hline
\end{tabular}

Figure 1. The influence among the different CSFs in Lean ERP implementation

The analysis of the figure 1 above, allowed us afterwards to draw the binary matrix $[\mathrm{M}]$ which is illustrated in figure 2 , to better visualize the influence of each factor separately, Then, through calculating the degree of influence of each factor, the result matrix could be plotted, where: 1 represents an influence and 0 doesn't represent any influence;

By analyzing the resulting matrix $[\mathrm{M}]$, we can conclude that there are 11 levels of influence, distributed as follows in Table 2:

These CSFs's levels and degrees of influence will contribute to an easy implementation of the Lean ERP combined system; Starting with the first levels of influence (high influence factors), it will contribute indirectly to the establishment of other factors influenced factors; This will automatically facilitate the implementation of the other CSFs, and thus a quick implementation of the hole system.

\section{Stakeholders Role in Lean ERP Implementation}

Stakeholders could be defined as the different parts involved in a process, hence their positive or negative impact; depending on their degree of contribution and influence on the project. Knowing that close cooperation of stakeholders is necessary for the success of the project [7].

Identifying how stakeholders influence the success of project through a continuous development of their relationships, is an important and fundamental issue of stakeholder management, that remain an account for the success of projects [8], and an important issue in project management [9]. It is necessary to know how the stakeholders can be influenced, so they support and contribute to the project [10]; As a project can be seen as a temporary coalition of stakeholders pursuing an aim together [7,9]. 
Table 2. CSFs's Degree of influence

\begin{tabular}{|c|c|c|}
\hline Level & $\begin{array}{l}\text { Degree Of } \\
\text { Influence }\end{array}$ & Factors \\
\hline Level 1 & 14 & $\mathrm{C} 2$ \\
\hline Level 2 & 13 & $\begin{array}{l}\mathrm{C} 1 \\
\mathrm{C} 4\end{array}$ \\
\hline Level 3 & 11 & $\mathrm{C} 10$ \\
\hline Level 4 & 9 & $\mathrm{C} 14$ \\
\hline Level 5 & 8 & $\begin{array}{l}\mathrm{C} 8 \\
\mathrm{C} 18 \\
\mathrm{C} 13\end{array}$ \\
\hline Level 6 & 7 & $\begin{array}{l}\mathrm{C} 11 \\
\mathrm{C} 19 \\
\mathrm{C} 6\end{array}$ \\
\hline Level 7 & 6 & $\begin{array}{l}\mathrm{C} 12 \\
\mathrm{C} 3 \\
\mathrm{C} 7\end{array}$ \\
\hline Level 8 & 5 & $\begin{array}{l}\mathrm{C} 17 \\
\mathrm{C} 9\end{array}$ \\
\hline Level 9 & 4 & $\begin{array}{l}\mathrm{C} 16 \\
\mathrm{C} 5\end{array}$ \\
\hline Level 10 & 3 & $\mathrm{C} 20$ \\
\hline Level 11 & 1 & $\mathrm{C} 15$ \\
\hline
\end{tabular}

The implementation of Lean ERP system is one of the complex project that need contribution and engagement of all part of the enterprises, due to the changes that will involve stakeholders.
These stakeholders typically have multiple and often conflicting interests and rarely agree on a set of common objectives [11].

\subsection{Classification according to Stakeholders Group}

Stakeholder involvement is essential when implementing a system such as Lean ERP; That provides high customer service and shorter lead times [12], which involves different parts of the enterprises. why is it important to consider the different categories of stakeholders to allow each group to focus on the relevant CSFs. Figure 3 shows the important groups of stakeholders. The Lean ERP implementation project involves all parts of the business. Therefore, the assessment of stakeholder groups is one of the important steps to establish when implementing the combined system.

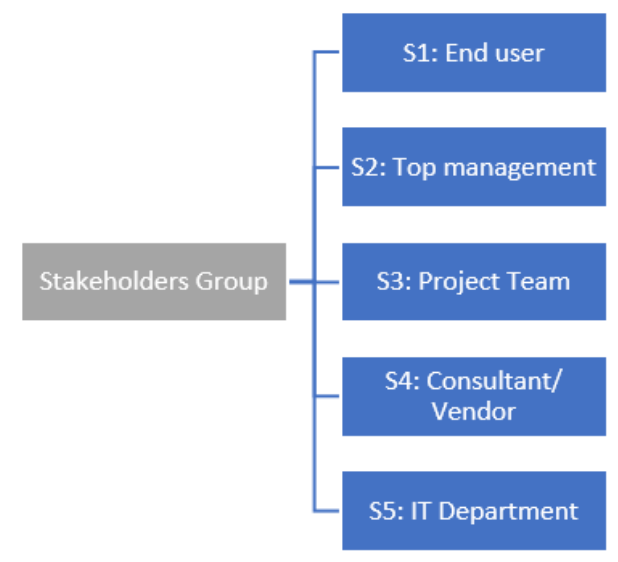

Figure 3. Classification of stakeholders groups

\subsection{Stakeholder Assessments}

Stakeholder assessments can assist planners to identify the interests, groups and individuals that are stakeholders in planning exercises, as well as their values, interests and relative power [13]. This can help to proactively determine ways to reduce negative impacts on the groups with less influence and power within the enterprise. A thorough stakeholder analysis can also identify potential conflicts or risks that could jeopardize the project, as well 
Table 3. Analysis of Stakeholder assessments

\begin{tabular}{|c|c|c|c|c|}
\hline Stakeholders & Role & Influence & Expectation & Issues \\
\hline End user & $\begin{array}{l}\text { Provide all the necessary business } \\
\text { processes } \\
\text { - Effective communication of IT needs } \\
\text { of the enterprise and its consultants }\end{array}$ & $\begin{array}{c}\text { Low } \\
\text { influence }\end{array}$ & $\begin{array}{l}\text { - solved Business process } \\
\text { - Centralized system } \\
\text { offering real and accurate } \\
\text { information }\end{array}$ & $\begin{array}{l}\text { - Lack of involvement in } \\
\text { decision-making }\end{array}$ \\
\hline $\begin{array}{c}\text { Top } \\
\text { Management }\end{array}$ & $\begin{array}{l}\text { - Provide the resources needed to } \\
\text { implement the project } \\
\text { - Set up a road map and an execution } \\
\text { plan } \\
\text { - Ensure stakeholders involvement }\end{array}$ & $\begin{array}{l}\text { Medium } \\
\text { influence }\end{array}$ & $\begin{array}{l}\text { - Successful implementation } \\
\text { of the combined system } \\
\text { - Minimize waste, reduce } \\
\text { costs to increase profits }\end{array}$ & $\begin{array}{l}\text { - Lack of support and } \\
\text { ongoing commitment } \\
\text { - Implementation of other } \\
\text { projects in parallel that } \\
\text { minimize starting resources }\end{array}$ \\
\hline $\begin{array}{l}\text { Project } \\
\text { Team }\end{array}$ & $\begin{array}{l}\text { - Application of business plans } \\
\text { developed by Top Management } \\
\text { - Good use of available resources } \\
\text { - Adopt lean philosophy throughout the } \\
\text { implementation of the Lean ERP } \\
\text { system } \\
\text { - Ensure stakeholders involvement }\end{array}$ & $\begin{array}{c}\text { High } \\
\text { influence }\end{array}$ & $\begin{array}{l}\text { - Accurate monitoring of the } \\
\text { plans and processes put in } \\
\text { place } \\
\text { - Provide relevant employees } \\
\text { with the necessary } \\
\text { information and } \\
\text { documentation in real time, } \\
\text { with precision. }\end{array}$ & $\begin{array}{l}\text { Anxious to be replaced by } \\
\text { the new system }\end{array}$ \\
\hline $\begin{array}{l}\text { Consultant / } \\
\text { Vendor }\end{array}$ & $\begin{array}{l}\text { Work methodically with internal } \\
\text { stakeholders } \\
\text { - Provide all the necessary } \\
\text { documentation and training } \\
\text { - Ensure the successful implementation } \\
\text { of the system }\end{array}$ & $\begin{array}{c}\text { High } \\
\text { influence }\end{array}$ & $\begin{array}{l}\text { - Successful and efficient } \\
\text { implementation of the } \\
\text { combined system } \\
\text { - Collaboration and support } \\
\text { of internal stakeholders }\end{array}$ & $\begin{array}{l}\text { - Lack of cooperation from } \\
\text { internal stakeholders }\end{array}$ \\
\hline $\begin{array}{c}\text { IT } \\
\text { Department }\end{array}$ & \begin{tabular}{ll} 
& \multicolumn{2}{l}{ Technical support } \\
- Collaboration with consultant/ \\
$\begin{array}{l}\text { Vendor and Project } \\
\text { Team to } \\
\text { guarantee }\end{array}$ an \\
$\begin{array}{l}\text { implementation of } \\
\text { system }\end{array}$
\end{tabular} & $\begin{array}{c}\text { Low } \\
\text { influence }\end{array}$ & $\begin{array}{l}\text { - Consolidation } \\
\text { decentralized IT groups } \\
\text { - Creation of a centralized IT } \\
\text { department }\end{array}$ & $\begin{array}{l}\text { - Lack of cooperation } \\
\text { - Lack of involvement in } \\
\text { decision making process }\end{array}$ \\
\hline
\end{tabular}

as opportunities and strategies for stakeholder engagement during implementation. Therefore, it is imperative to identify and engage all stakeholders early on in the project to ensure the proper measures are in place to manage the different characteristics of these stakeholders. Taking this initiative will increase the likelihood of successful implementation and adoption of the enterprise system [14]. Table 3 summarizes the assessment of stakeholder's groups including their role, degree of influence, expectations and issues related to Lean ERP implementation.

The stakeholder groups mentioned above have multiple interactions with each other within the organization, which is essential to the smooth running of the business, which has prompted our team of researchers and industrialists to draw the matrix $[S]$ (Figure 4 ) which standardize the degree of similarity and interactions over an interval of 0 to 1 .

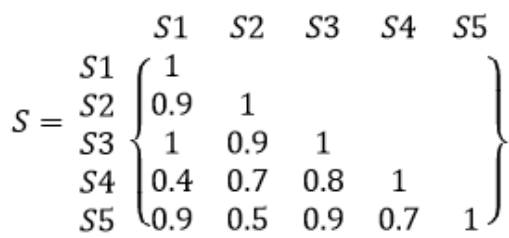

Figure 4. The binary Matrix [S]

Afterwards, we used the color-coding approach in figure 5to illustrate the different interactions of the stakeholder network. The color ranges from turquoise to gray to indicate the degree of interaction of the stakeholder network. If the links colors are closer to gray then we have a higher degree, which means that related stakeholders have a closer connection and stronger influence over each other. On the other hand, the colors closer to turquoise are not very marked, which means that the related stakeholders have a fragile relationship and a weaker influence on each other. Table 4 presents this classification that will help stakeholders of the enterprise to focus on factors that affect them.

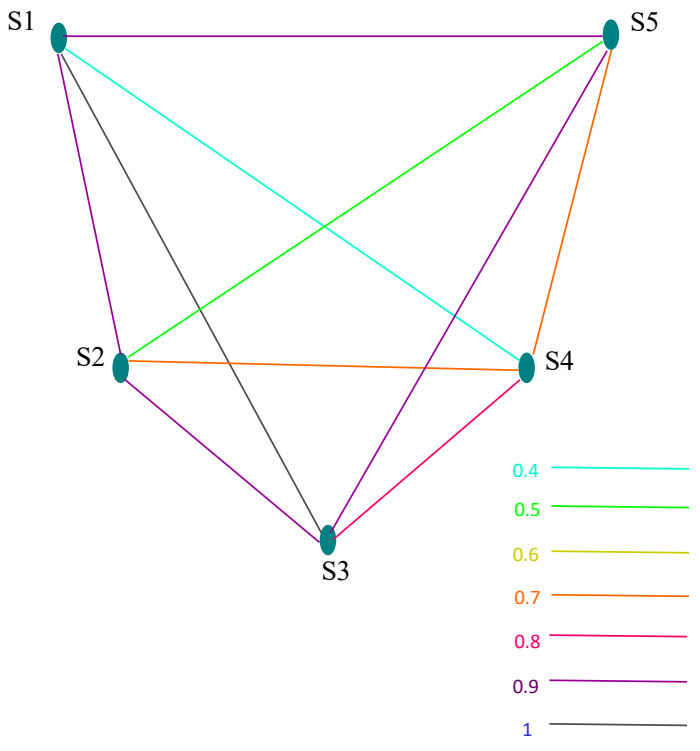

Figure 5.Relationships among Stakeholders network 


\section{Houti et al. / Advances in Science, Technology and Engineering Systems Journal Vol. 4, No. 6, 443-447 (2019)}

Consequently, a classification according to Stakeholders Group of CSFs gathered during the previous study will be established to help further enterprises and its stakeholders to focus on CSFs that affect them directly in order to reach a better performance and a successful implementation of the hybrid Lean ERP system.

Table 4. Classification of Lean ERP CSFs according to stakeholders group

\begin{tabular}{|c|c|c|c|c|c|}
\hline $\begin{array}{c}\text { CSF } \backslash \\
\text { Stakeholders } \\
\text { Group } \\
\end{array}$ & S1 & S2 & S3 & S4 & S5 \\
\hline C1. & & X & & & \\
\hline $\mathrm{C} 2$. & & X & $X$ & & \\
\hline C3. & & X & X & & \\
\hline C4. & & X & & & \\
\hline C5. & $X$ & & X & & $X$ \\
\hline C6. & X & & X & & \\
\hline C7. & & $\mathrm{X}$ & & & $X$ \\
\hline C8. & & $X$ & & X & X \\
\hline C9. & & & X & & \\
\hline C10. & & $X$ & & & \\
\hline C11. & & & & & $X$ \\
\hline $\mathrm{C} 12$. & X & & X & & \\
\hline C13. & & & X & X & X \\
\hline C14. & X & & & & \\
\hline C15. & & $X$ & X & X & \\
\hline C16. & & X & & & $X$ \\
\hline C17. & $X$ & X & & $X$ & \\
\hline C18. & & $X$ & & X & \\
\hline C19. & $X$ & & & $X$ & \\
\hline C20. & & X & X & & \\
\hline
\end{tabular}

\section{Conclusion}

The Lean ERP system has become the most widely adopted system by enterprises, as long as the many advantages that presents. However, the high cost of implementation and the risk of failure can lead to several critical issues within the enterprise and its different stakeholders, which could be solved by taking into account the CSFS and involving different stakeholders groups during the implementation of the hybrid system.

This article has enabled us to extract, 20 most CSFs to be used when implementing the hybrid Lean ERP system, thereafter study in more detail their degree of influence to further identify the factors to take into account as a priority, depending on their Level of influence, in order to simplify the implementation of other factors that affect them. Thereafter analyze the importance of the identified stakeholder groups (End user, Top Management, Project
Team, Consultant / Vendor, IT Department) and study their interactions to help future enterprises wishing to implement the hybrid system and their stakeholders to concentrate on the CSFs that directly affect each Stakeholder group in order to achieve better performance and successful implementation of the hybrid Lean ERP system.

\section{References}

[1] Houti, M., El Abbadi, L., Abouabdellah, A., "E-Kanban the new generation of traditional Kanban system, and the impact of its implementation in the enterprise ", Proceedings of the International Conference on Industrial Engineering and Operations Management, IEOM., Rabat, Morocco, (Apr, 1113), 2017.

[2] Houti, M., El Abbadi, L., Abouabdellah, A., "External critical successful factors for a successful implementation of ERP systems", Proceedings of International Conference on Computers and Industrial Engineering, CIE., Lisbon, Portugal, (Oct, 11-13), 2017.

[3] Houti, M., El Abbadi, L., Abouabdellah, A., "Lean ERP: A hybrid approach Push /Pull", Proceedings of the 3rd IEEE International Conference on Logistics Operations Management, GOL 2016., Fez, Morocco, (May, 23-25), 2016.

[4] Houti, M., El Abbadi, L., Abouabdellah, A., "Critical Success Factors for Lean implementation "Projection on SMEs", Proceedings of the International Conference on Industrial Engineering and Operations Management, IEOM., Pilsen, Czech Republic, (Jul, 23-26), 2019.

[5] Hofer, C. W., Schendel, D. A., "Strategy Formulation: Analytical Concepts", West Publishing Company, Saint Paul, 1978.

[6] Dag, N., "Lean and Six Sigma - critical success factors revisited", International Journal of Quality and Service Sciences, Vol. 5, №.1, (2013), pp. $86-100$.

[7] Jepsen, A.L., Eskerod, P., "Stakeholder analysis in projects: Challenges in using current guidelines in the real world", International Journal of Project Management, Vol. 27, (2009), pp. 335-343.

[8] McElroy, B.; Mills, C. "Managing stakeholders", In Gower Handbook of Project Management; Turner, R.J., Simister, S.J., Eds.; Gower: Aldershot, UK, 2000.

[9] Andersen, ES., "Prosjektledelse - et organisasjonsperspektiv", Bekkestua: NKI Forlaget, Oslo, 2005.

[10] Lund Jepsen, A., Eskerod, P., "Stakeholder analysis in projects: Challenges in using current guidelines in the real world", International Journal of Project Management, Vol. 27, (2009), pp. 335-343.

[11] Sudevan, S., Bhasi, M., Pramod, K.V., "Interpreting Stakeholder Roles in ERP Implementation Projects: A Case Study", International Journal of Computer Science and Information Technologies, Vol. 5 (3), (2014), pp. 3011-3018.

[12] Houti, M., El Abbadi, L., Abouabdellah, A., "How Could an Urgent Order Disturb the Supply Chain? Case S tudy of an Automotive Industry", International Journal of Engineering \& Technology, Vol. 7(4.16), (2018), pp. 155-159.

[13] Medeiros de Araujo. L., Bramwell. B., "Stakeholder Assessment and Collaborative Tourism Planning: The Case of Brazil's Costa Dourada Project", Journal of Sustainable Tourism, Vol. 7(3-4), (1999), pp.356-378.

[14] McLaren, T., Jariri, I., "Stakeholder Assessment and Management for Enterprise Systems Implementation Projects", International Conference on Information Resources Management, CONF-IRM 2012 Proceedings, Association for Information SystemsAIS Electronic Library (AISeL) (sep, 26), 2012. 